\title{
PRINSIP SALING TOLERANSI (TASAMUH) PADA RESTORAN ALL YOU CAN EAT MENURUT PERSPEKTIF ISTIHSAN
}

\author{
Umi Atia Hanik \\ Universitas Islam Negeri Sunan Ampel Surabaya \\ e-mail: umiatiahanik01@,gmail.com
}

\begin{abstract}
Abstact
This study aims to determine the principle of mutual tolerance (tasamuh) in the all you can eat restaurant from the istihsan perspective. The research method used in this research (library research) is a qualitative approach. The data sources of this research are books and journals that are analyzed using the Miles and Huberman analysis method which includes three lines, namely data reduction, data presentation and drawing conclusions or verification. The results of this study conclude that the principle of mutual tolerance (tasamuh) in all you can eat restaurant according to the istihsan perspective is allowed based on 'urf because it has become a habit of today's society which will be difficult to avoid but still we should not go to waste in taking food because it is hated by god.
\end{abstract}

Keywords: Buying and Selling, tasamuh, istihsan

\section{A. PENDAHULUAN}

Jual beli merupakan kegiatan dan didalam kegiatan tersebut ada seorang penjual dan pembeli atau bisa lebih. Jual beli bukan hanya ada di Indonesia saja melainkan di seluruh dunia juga melakukan yang namanya kegiatan jual beli.

Dalam jual beli banyak sekali barang yang diperdagangkan. Mulai dari kebutuhan primer, sekunder bahkan tersier.

Kebutuhan primer merupakan kebutuhan pokok atau kebutuhan yang tidak terpenuhi maka bisa menyebabkan orang tersebut tidak bisa bertahan hidup, seperti: makanan, pakaian dan tempat tinggal.

Kebutuhan sekunder adalah kebutuhan yang dipenuhi setelah kebutuhan primer terpenuhi dan kebutuhan ini merupakan usaha untuk menciptakan dan menambah kebahagiaan hidup. Seperti: pendidikan, akses kesehatan, serta hiburan.

Yang terakhir adalah kebutuhan tersier. Kebutuhan ini merupakan kebutuhan untuk meningkatkan harga diri dan gengsi.

Di dalam kegiatan jual beli terjadi maka, apabila pembeli menyukai barang yang diperjualkan oleh pedagang maka akan dilakukan proses transaksi.

Di dalam transaksi jual beli sekarang ini banyak sekali yang menggunakan dengan metode yang baru yaitu dengan tidak adanya akad ijab dan qobul yang seseorang hanya 
mengambil barang dan membayarnya tanpa ada kata ini saya beli dan ini saya jual. Meskipun masih ada juga yang menggunakan akad ijab dan qobul walaupun tidak banyak. Dalam hal ini (tidak adanya ijab dan qobul) tentu diperbolehkan karena perkembangan zaman dan sudah menjadi kebiasaan.

Begitu juga dengan dengan kehidupan anak zaman sekarang banyak sekali orang yang sudah menjadi kebiasaan untuk memenuhi kebutuhan primernya seperti jual beli makanan diluar. Di dalam jual beli makanan ini juga terdapat banyak tempatnya, seperti: restoran, warung, hotel dan lain sebagainya.

Model dalam penjualannya pun bermacam-macam. Ada yang prasmanan dan ada yang diambilkan oleh pihak penjual. Dalam pembayarannya pun bermacammacam. Ada yang mengambil barang dan membayar sesuai dengan kuantitas barangnya dan ada pula yang membayar tanpa melihat kuantitas seperti halnya tempat makan atau restoran all you can eat.

Restoran atau tempat makan all you can eat adalah sistem dalam penjualannya yaitu dengan satu kali membayar dan bisa menikmati semua menu yang sudah disediakan dari tempat makan tersebut dan menggunakan konsep prasmanan atau buffet. Secara umum yang dinamakan all you can eat yaitu semua bisa dimakan.

Istihsan yaitu mencari solusi yang terbaik untuk kemaslahatan umat. Mencari solusi yang terbaik untuk masalah penjualan dengan sistem all you can eat tersebut sangatlah penting. Karena menurut figh muamalah itu tidak diperbolehkan karena kuantitas barangnya masih belum jelas jumlahnya.

Permasalahan diatas juga pernah dilakuakan oleh Dewi Puryanti, Rosani, dan Dahlia Haliyah Ma'u yang berjudul Ushul Fiqh dan Maqashid Syariah Tentang Istihsan Dalam Ekonomi Syariah. Didalamnya berisi tentang Istihsan merupakan salah satu metode istinbath hukum yang dapat dijadikan hujjah, karena banyak hal yang telah diselesaikan dengan metode istihsan dan telah ditetapkan hukumnya. Nampaknya hukum yang ditetapkan dengan istihsan lebih mengayomi dan lebih mampu merealisasi tujuan syariat. Istihsan mempunyai relevansi dengan pembaruan hukum Islam

\section{B. METODE PENELITIAN}

Penelitian ini menggunakan jenis penelitian berupa studi kepustakaan (library research), dalam hal ini terkait dengan "Prinsip Saling Toleransi (Tasamuh) Pada Restoran All You Can Eat Menurut Perspektif Istihsan" dengan menggunakan pendekatan kualitatif. Sumber data yang dijadikan acuan dalam penulisan penelitian ini berupa beberapa buku.

Metode dalam analisis data yang dipakai penelitian ini menggunakan analisis deskriptif dan menggunakan metode analisis Miles dan Huberman yang meliputi tiga alur, yakni reduksi data, penyajian data dan penarikan kesimpulan atau verifikasi.

Reduksi data pada penelitian ini yaitu dengan cara menyederhanakan data, memilah halhal pokok yang sesuai dengan penelitian. Langkah selanjutya yaitu penyajian data dengan memproses pengorganisasian data yang telah diperoleh guna memudahkan untuk dianalisis dan disimpulkan. Setelah itu dilakukan penarikan kesimpulan atau 
verifikasi yang merupakan langkah terakhir dalam proses analisis.

\section{HASIL DAN PEMBAHASAN Definisi Jual Beli}

Secara etimologi, pengertian jual beli adalah adanya dua perbuatan dalam satu kejadian pihak pertama bertindak sebagai penjual dan yang satunya lagi sebagai pembeli. Dari peristiwa tersebut terjadilah hukum jual beli.

Di dalam fikih, jual beli disebut dengan $a l-b a$ ' $i$ yang mempunyai arti menjual, menukar, dan mengganti sesuatu dengan yang lain. didalam bahasa arab lafal al-ba'i terkadang digunakan untuk pengertian lawannya, yaitu kata as-syira' (beli). Maka, kata $a l-b a$ ' $i$ bukan hanya berarti jual namun juga berarti beli.

Pengertian jual beli secara termologi yang telah dikemukakan oleh para ulama fiqh, sekalipun substansi dan tujuannya memiliki definisi yang sama.

Definisi jual beli menurut Sayyid Sabiq adalah :

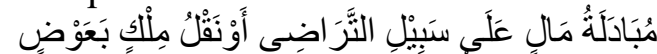

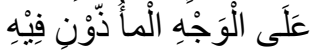

"Jual beli ialah pertukaran harta dengan harta atas dasar saling merelakan". Atau, memindahkan milik dengan ganti yang dapat dibenarkan."

Sedangkan menurut Hanabilah, jual beli adalah:

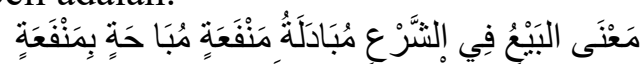

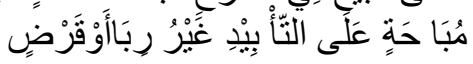

"Pengertian jual beli menurut syara' adalah tukar menukar harta dengan harta, atau tukar menukar manfaat yang mubah dengan saling tukar menukar harta dengan harta dalam bentuk pemindahan milik."

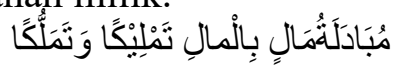

"Saling menukar harta dengan dalam bentuk pemindahan milik dan pemilikan"

Berdasarkan pengertian diatas maka dapat dipahami bahwa jual beli menekankan pada tukar menukar harta dan melepaskan hak milik dari satu ke yang lain, pertukaran ini berupa uang dengan barang. Dahulu orang jual beli barang dengna barang namun dizaman sekarang ini berbeda dengan zaman dahulu yaitu uang dengan barang. Pertukaran barang dengan barang pada zaman dahulu dinamakan barter. Seperti, gandum atau beras dari luar negeri ditukar dengan kopi atau lada dari Indonesia dalam jumlah yang besar.

\section{Rukun dan Syarat Jual Beli}

Rukun jual beli ada empat menurut jumhur Ulama':

1. Ada orang yang melakukan akad atau adanya penjual dan pembeli (muta'aqidain)

2. Adanya sighat (lafal ijab dan qabul)

3. Ada barang yang diperjualbelikan.

4. Ada nilai tukar sebagai pengganti barang.

Sedangkan untuk syarat-syarat jual beli yaitu:

1. Syarat orang yang melakukan akad

Para Ulama' Fiqh telah menyetujui bahwa orang yang sedang melakukan akad dalam jual beli harus memenuhi syarat berikut:

a) Berakal

Berakal yang dimaksud ini adalah bukan anak kecil, orang gila maupun orang bodoh. Apabila ada syarat diatas maka tidak sah hukumnya. 
Namun berbeda, apabila anak kecil yang mumayyiz. Menurut Ulama' Hanafiyah menjelaskan bahwa akad yang dilakukan membawa keuntungan untuk dirinya maka akadnya sah. Namun apabila membawa kerugian maka tidak sah hukumnya.

Selain anak kecil yang mumayyiz, yang sah dalam akad jual beli adalah orang yang baligh dan berakal.

b) Yang melakukan akad adalah orang yang berbeda

Disaat melakukan akad maka orang tersebut tidak melakukan peran ganda yang bertindak sebagai penjual dan pembeli.

2. Syarat tentang Ijab dan Qabul

Ijab adalah perkataan dari penjual, seperti "saya jual barang ini dengan harga sekian". Qobul adalah perkataan pembeli, seperti "saya beli barang ini dengan harga sekian". Maka saat melakukan transaksi harus melakukan pembicaraan diatas maka dianggap sah dalam jual beli.

Namun di zaman sekarang ini perwujudan ijab dan qobul ini tidak dilakukan dengan ucapan melainkan dengan tidakan sperti mengambil barang dan membayarnya.

3. Syarat barang yang diperjualbelikan (Al-Mu'qad alaih) a. Suci

b. Barang yang diperjualbelikan milik sendiri

c. Barang yang diperjualbelikan ada manfaatnya

d. Barang yang diperjualbelikan dapat diketahui e. Barang yang diakadkan ada
ditangan dan dapat
diserahkan
berlangsungnya akad.

\section{Definisi Toleransi (Tasamuh)}

Toleransi (tasamuh) yaitu sikap yang memperbolehkan yang berarti tidak menolak pendapat, sikap, ataupun gaya hidup yang tidak sama. Didalam implementasinya, sikap toleransi bukan hanya dilakukan pada hal-hal yang berkaitan dengan aspek moral dan spiritualyang tidak sama, melainkan dilakukan pada aspek yang lebih luas, termasuk aspek politik dan ideologi yang berbeda.

Dalam bahasa Arab, istilah yang biasa digunakan sebagai padanan dari kata toleransi adalah تسامح atau سما (aي). Kata ini berarti جيد (kemuliaan), atau التسامح (lapang dada) dan ساعةالصدر (ramah, suka memaafkan). Selanjutnya, makna ini berkembang menjadi sikap yang terbuka/lapang dada dalam menghadapi perbedaan yang bersumber dari kepribadian yang mulia. Apabila tolerance mengandung makna keterpaksaan, berbeda dengan tasamuh yaitu keikhlasan.

Sikap toleransi menurut Islam dan dijelaskan di dalam Al-Qur'an, menjelaskan bahwa bukan hanya mengharapkan namun juga menerima kenyataan dan dengan adanya keragaman dan perbedaan di dalam masyarakat. Di dalam surat al-Hujurat ayat 13 dijelaskan, bahwa tidak ada yang namanya diskriminasi terhadap satu orang ke orang lain dan sikap saling menghargai antara satu dengan yang lain karena yang menjadi pembeda di mata Allah adalah ketakwaan seorang hamba kepada Rabb-Nya. Dari sini bisa dijelaskan bahwa Allah saja memerintahkan 
manusia untuk saling toleransi, apalagi kita sebagai manusia maka tidak boleh kita semena-mena terhadap orang lain. baik itu yang mempunyai perbedaan sosial dari kita maupun perbedaan suku, ras, warna kulit dan lain sebagainya.

Prinsip di tasamuh yaitu sebagai titik pengalaman hukum islam karena manusia mempunyai fikiran yang berbeda-beda, maka dari itu antara manusia yang satu dengan yang lain harus saling menghargai dan mengakui bahwa pemikiran manusia itu bersifat relatif.

Toleransi merupan ajaran yang mendasar dalam agama Islam. karena dengan adanya toleransi maka akan berimplikasi pada sikap saling menghargai, menghormati dan memahami satu dengan yang lain.

\section{Ruang Lingkup Toleransi}

Di dalam ruang lingkup toleransi bisa dianalisa sebagai berikut:

a. Mengakui Hak Orang Lain

Mempunyai sikap yang mau mengakui hak orang lain dalam menentukan sikap/tingkah laku dan nasibnya masing-masing merupakan sikap atau tingkah lakunya tidak melanggar hak orang lain.

b. Menghormati Keyakinan Orang Lain

Setiap orang yang mempunyai keyakinan pada dirinya itu adalah berdasarkan pada kepercayaannya. Kepercayaan tersebut telah tertanam di dalam hati dan mempunyai landasan yang kuat baik berupa wahyu maupun pemikiran yang rasional. Karena, setiap orang yang mempunyai keyakinan tentu tidaklah mudah untuk dirubah atau dipengaruhi.

c. Agree and Disagreement (Setuju dalam Perbedaan)

Di dalam prinsip perbedaan tidaklah harus ada permusuhan karena setiap orang pasti mempunyai perbedaan karena mengingat adanya keberagaman dalam kehidupan ini.

d. Saling Mengerti

Dengan adanya unsur saling mengerti makan sudah bisa dipastikan akan terwujud tolerasinya, karena ini adalah unsur yang paling penting.

e. Kesadaran dan Kejujuran

Dengan adanya kejujuran yang ada di dalam diri seseorang maka tidak akan ada pertengkaran yang terjadi antara sikap dan batinnya. Kalau kita mengingat di dalam membangun bangsa tentu sikap kebersamaan, empati, saling menghormati, mengorbankan kepentingan pribadi, kelompok dan golongan tentu saja harus dimiliki agar bisa mencapai tujuan bersama yaitu membangun bangsa.

\section{Definisi Istihsan}

Istihsan dalam bahasa arab artinya menganggap sesuatu itu baik atau mengikuti sesuatu yang baik atau mengganggap baik/bagus.

Berikut adalah pengertian istihsan menurut bahasa dari beberapa Ulama' Ahli Ushul :

1. Menurut al-Sarakshi istihsan menurutbahasa adalah:

$$
\text { مأمو ربه الأ حسن للإتبّاع الذى هو }
$$

Berusaha mendapatkan yang terbaik untuk diikuti bagi sesuatu masalah yang diperhitungkan untuk 
dilaksanakan. Selain itu alSakhrasi juga menyebutkan bahwa:

$$
\text { الإستحسان هو ترك القياس و العمل بما هو }
$$

أقوى منه لاليل يقتضى ذلان ونى وفقا لمصلحة الناس

"Istihasan adalah meninggalkan qiyas dan menggunakan yang lebih kuat daripadanya, karena adanya dalil yang menghendaki dan lebih sesuai untuk merealisasikan kemaslahatan manusia."

2. Sedangkan menurut Abu al-Ahsan al-Karkhi yang merupakan seorang ulama' ushul dari madzhab Hanafi, istihsan adalah:

$$
\begin{aligned}
& \text { هو أن يعدل المجتهد عن أن يحكم فى المسألة }
\end{aligned}
$$

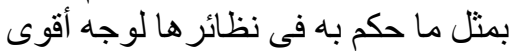

$$
\begin{aligned}
& \text { يقتضى العدول عن الأوّل } \\
& \text { Istihsan adalah }
\end{aligned}
$$

berpindahnya seorang mujtahid dari hal penetapan hukum pada suatu masalah yang secara subtansial serupa dengan apa yang telah ditetapkan karena terdapat alasan yang lebih kuat yang menghendaki perpindahan tersebut.

\section{Dasar Hukum Istihsan}

Mazhab yang menggunakan dalil istihsan adalah mazhab Hanafi. Menurut mazhab Hanafi istihsan semacam qiyas, yaitu memenangkan qiyas jali atau mengubah hukum yang sudah umum menjadi khusus karena adanya suatu peristiwa atau kejadian dan kepentingan yang membolehkannya. Selain mazhab Hanafi yang menggunakan dalil istihsan adalah sebagian mazhab Maliki dan mazhab Hambali.

Dengan adanya mazhab yang menggunakan dalil istihsan maka ada juga mazhab yang menentang dalil tersebut yaitu mazhab Syafi'i. Mazhab Syafi'i berpendapat bahwa berhujjah dengan istihsan adalah menetapkan hukum shara' berdasarkan hawa nafsu sendiri, sedangkan yang menetapkan hukum syara' hanya Allah SWT semata.

Para ulama' yang menerima istihsan sebagai dalil hukum, beliau mengembalikan asar istihsan kepada Al-Qur'an dan as-Sunnah. Berikut adalah dalil dari Al-Qur'an antara lain:

1. Surat Az-Zumar ayat 17-18

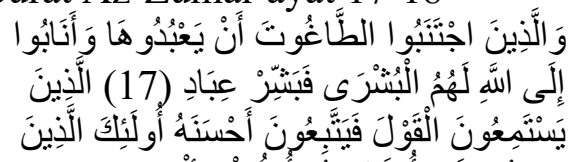

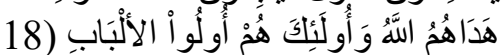
"Dan orang-orang yang menjauhi tagut (yaitu) tidak menyembahnya dan kembali kepada Allah, bagi mereka berita gembira; sebab itu sampaikanlah berita itu kepada hamba-hamba-Ku, yang mendengarkan perkataan, lalu mengikuti apa yang paling baik di antaranya. Mereka itulah orangorang yang telah diberi Allah petunjuk dan mereka itulah orangorang yang mempunyai akal."

2. Surat Al-A'raf ayat 145

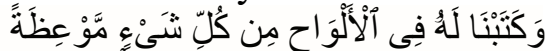

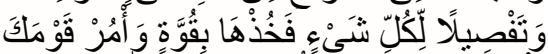

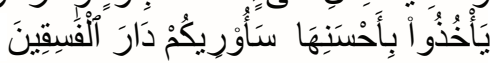

"Dan telah Kami tuliskan untuk Musa pada luh-luh (Taurat) segala sesuatu sebagai pelajaran dan penjelasan bagi segala sesuatu; maka (Kami berfirman): "Berpeganglah kepadanya dengan teguh dan suruhlah kaummu berpegang kepada (perintahperintahnya) dengan sebaikbaiknya, nanti Aku akan memperlihatkan kepadamu negeri orang-orang yang fasik." 
3. Surat Al-Baqarah ayat 185

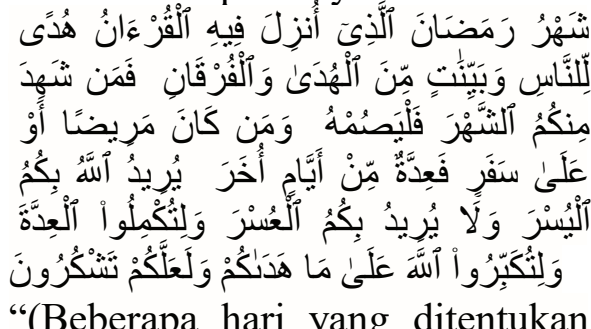
"(Beberapa hari yang ditentukan yang di dalamnya diturunkan (permulaan) Al Quran sebagai petunjuk bagi manusia dan penjelasan-penjelasan mengenai petunjuk itu dan pembeda (antara yang hak dan yang bathil). Karena itu, barangsiapa di antara kamu hadir (di negeri tempat tinggalnya) di bulan itu, maka hendaklah ia berpuasa pada bulan itu, dan barangsiapa sakit atau dalam perjalanan (lalu ia berbuka), maka (wajiblah baginya berpuasa), sebanyak hari yang ditinggalkannya itu, pada hari-hari yang lain. Allah menghendaki kemudahan bagimu, dan tidak menghendaki kesukaran bagimu. Dan hendaklah kamu mencukupkan bilangannya dan hendaklah kamu mengagungkan Allah atas petunjuk-Nya yang diberikan kepadamu, supaya kamu bersyukur."

4. Hadist Riwayat Al-Bukhari

من سلف في تمر فليسلف في كيل معلوم ووزن

"Barangsiapa yang melakukan jual beli kurma dengan cara assalaf, maka hendaklah melakukannya dalam takaran dan timbangan yang jelas (dan) untuk jangka waktu yang jelas pula". (HR. Al-Bukhari, No. 2240)

\section{Macam-Macam Istihsan}

\section{Istihsan Qiyasi}

Istihsan qiyasi adalah mengalihkan hukum dari qiyas jali menuju kepada qiyas khafi karena ada alasannya dan alasan itu adalah untuk kemaslahatan.

Contoh : Lahan Pada Pertanian

Didalam qiyas jali, wakaf sama juga dengan jual beli karena yang punya lahan pertanian sudah menggugurkan hak miliknya dengan cara memindah tangankan lahan tersebut. Jadi hak untuk mengalirkan air ke lahan pertanian tidak termasuk dalam akad wakaf itu kecuali jika dinyatakan dalam akad. Sedangkan menurut qiyas khafi wakaf yang dimaksud diatas adalah sama dengan sistem sewa menyewa karena maksud dari wakaf itu adalah memanfaatkan lahan pertanian yang sudah diwakafkan. Jadi, seluruh kegiatan yang terjadi selama masih melewati lahan pertanian tersebut termasuk mengaliran air adalah termasuk kedalam akad wakaf meskipun tidak tercatat secara jelas di dalam akad tersebut.

2. Istihsan Istisna' $i$

Istihsan istisna' $i$ adalah qiyas yang mengecualikan hukum yang umum menjadi hukum yang bersifat khusus. Istihsan Istisna' $i$ dibagi menjadi beberapa macam sebagai berikut:

a. Istihsan berdasarkan Nash (istihsan berdasarkan ayat atau hadis)

Istihsan berdasarkan Nash adalah penyimpangan ketentuan hukum qiyas kepada ketentuan hukum yang berlawanan dengan yang ditetapkan berdasarkan nash Al-Qur'an dan Sunnah. 
b. Istihsan berdasarkan Ijma'

Istihsan berdasarkan Ijma' adalah mengalihkan dari hukum yang umum kepada ketentuan hukum yang khusus karena adanya ijma' yang mengecualikan atau meniggalkan qiyas di suatu masalah sebab adanya ijma'.

c. Istihsan berdasarkan 'urf (tradisi)

Istihsan berdasarkan 'urf adalah meninggalkan konsekuensi qiyas menuju hukum lain yang berbeda karena 'urf. Sebagian ulama' berpendapat bahwa wakaf bisa dari barang-barang yang bergerak, seperti: wakaf buku, mobil, dan barang-barang lainnya.

Di dalam kaidah umum, wakaf harus barang yang tidak bisa bergerak seperti tanah atau bangunan. Namun karena sudah menjadi kebiasaan di masyarakat menggunakan wakaf barang bergerak maka para Ulama membolehkannya.

d. Istihsan berdasarkan adDarurah (kedaruratan)

Istihsan berdasarkan adDarurah adalah adanya keadaan darurat yang membuat seorang mjtahid tidak memberlakukan kaidah umum atau qiyas.

e. Istihsan berdasarkan maslahah mursalah

Istihsan berdasarkan maslahah mursalah adalah mengesampingkan ketentuan yang ada pada hukum qias untuk maslahat yang lebih penting.
Prinsip Saling Toleransi (Tasamuh) Pada Restoran All You Can Eat Menurut Perspektif Istihsan

Dizaman modern ini banyak sekali orang lebih senang untuk membeli makan diluar, bahkan ini sudah menjadi budaya. Selain hanya untuk kumpul dengan teman, atau mencoba aneka makanan yang baru. Bahkan banyak juga orang yang membeli karena tergiur dengan diskon yang dibuat oleh para penjual.

Tempat yang digunakan untuk membeli makanan pun bervariasi, mulai dari di warung, di restaurant, di hotel dan masih banyak yang lain lagi. Selain tempat, cara penyajiannya pun bervariasi seperti prasmanan (ambil makanan dan minuman sendiri) atau diambilkan oleh pihak penjual. Namun sekarang ini sudah marak sekali tempat makanan yang prasmanan. Selain penjual tidak perlu bersusah payah untuk melayani pembeli dengan cara mengambilkan makanan yang diinginkan oleh pembeli, pihak penjual juga tidak perlu membuang banyak makanan karena pembeli yang mengambil sendiri makanannya dan mengerti seberapa besar makanan dan minuman yang bisa dimakan dan diminum oleh pembeli. sehingga tidak ada yang namanya mubadzir atau membuang-buang makanan karena tidak habis.

Istihsan dalam bahasa arab artinya menganggap sesuatu itu baik atau mengikuti sesuatu yang baik atau mengganggap baik/bagus.

Baik dalam kalimat diatas adalah mencari solusi yang terbaik sesuai dengan zaman sekarang ini. Namun tentu saja tidak semua orang yang bisa menentukan hukum istihsan karena harus berdasarkan dalil-dalil yang ada 
karena tidak sembarangan untuk menentukan apakah bisa di istihsankan atau tidak.

Dalam hal ini istihsan mempunyai banyak sekali macamnya, yang salah satunya adalah istihsan berdasarkan 'urf. 'Urf disini berarti kebiasaan. Kebiasaan tersebut sudah terbentuk didalam masyarakat dan sulit untuk dihilangkan. Di dalam istihsan, 'urf diperbolehkan asalkan kebiasaan tersebut adalah kebiasaan yang baik dan ttidak melanggar syariat islam.

Seperti halnya kebiasaan seseorang makan di restauran all you can eat, semua orang bisa makan sepuasnya ditempat dengan cara membayar dan mengambil makanan sendiri sampai dia kenyang namun tetap ada waktu yang ditetentukan oleh pihak restauran. Waktu yang ditentukan biasanya 2 jam.

Di dalam restaurant ini kita bisa mengambil banyak atau sedikit namun tetap bayarnya sama. Jadi, meskipun kita ambil 1 jenis makanan dengan orang yang ambil 5 jenis makanan maka bayarnya tetap sama karena yang ditentukan bukan kuantitas makanan yang kita makan melainkan harga awal yang sudah disepakati oleh pihak penjual dan pembeli.

Dari sini kita bisa melihat bahwa kuantitas barangnya tidaklah sama maka dalam fiqh muamalah tidaklah sah karena tidak jelasnya perhitungan jumlah barang dan jumlah uangnya. Namun, karena ini sudah menjadi adat kebiasaan di masyarakat dan sudah banyak sekali restoran yang mempunyai sistem seperti ini maka diperbolehkan dengan cara tasamuh (toleransi).

Didalam toleransi tersebut maka pihak penjual maupun pembeli harus saling rela (tidak ada salah satu pihak yang tidak setuju), karena mengingat bisa jadi orang tersebut makan lebih banyak dan mengakibatkan uang yang diterima tidak sama dengan barang yang diperjual belikan. Begitu pula dengan pembeli yang harus rela, apabila yang dia makan ternyata tidak sama dengan uang yang dikeluarkan atau merasa rugi karena hanya bisa makan lebih sedikit dari jumlah uang yang sudah kita bayarkan kepada pihak penjual.

Dari sini apabila kita bisa mewujudkan sikap tasamuh (toleransi) maka tidak akan terjadinya pertengkaran antara pihak penjual dan pembeli.

Namun dari restoran ini ada yang menarik yaitu apabila makanan yang tidak habis maka ada denda disana (yang dimaksud tidak habis yaitu apabila kita sudah mengambil makanan namun ternyata kita tidak sanggup menghabiskan makananya dan masih tersisa di piring yang kita buat makan). Denda yang diberikan oleh pihak restauran atau tmepat makan yang kita gukanan untuk makan juga bervariasi tergantung keputusan tiap-tiap tempat makannya. Meskipun kita melakukan sikap tasamuh namun tetap kita tidak boleh mubazir terhadap makanan. Seperti yang ada di dalam al-qur'an, surat alisra' ayat 27:

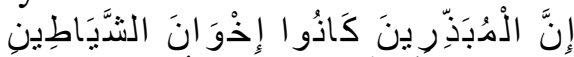

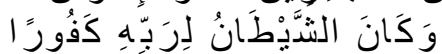

"sesungguhnya orang-orang yang pemboros itu adalah saudara setan dan setan itu sangat ingkar kepada tuhannya"

Dari sini kita bisa melihat bahwa Allah tidak menyukai sikap mubazir. Jadi meskipun kita boleh ambil sepuasnya namun tetap harus tahu 
porsi makan yang sanggup kita makan sampai berapa banyak.

\section{KESIMPULAN}

Istihsan dalam bahasa arab artinya menganggap sesuatu itu baik atau mengikuti sesuatu yang baik atau mengganggap baik/bagus

Restoran all you can eat itu dilarang menurut ilmu fiqh mu'amalah karena tidak jelasnya kuantitas barang yang dibeli dengan harganya. Namun, didalam prinsip saling toleransi (tasamuh) pada restoran all you can eat menurut perspektif istihsan diperbolehkan berdasarkan 'urf (kebiasaan) karena itu sudah menjadi kebiasaan pada masyarakat sekarang ini yang sulit untuk dihindarkan.

Pada penelitian in terdapat keterbatasan penelitian yang dialami oleh penulis, seperti objek penelitian yang hanya dilakukan pada restoran all you can eat dan dianalisis menggunakan prinsip tasamuh perspektif istihsan saja. Sedangkan prinsip tasamuh berdasarkan perspektif istihsan dalam makanan all you can eat diperbolehkan asal tidak mubadzir.

\section{REFERENSI}

[1] A. Hadziq, dkk, Kapita Selekta Kerukunan Umat Beragama. Semarang: Forum Kerukunan Umat Beragama, 2008.

[2] A. Rahman Dahlan, Ushul Fiqh. Jakarta: Pustaka Amzah, 2011.

[3] A. Rahman Gazaly, Fiqh Muamalah. Jakarta: Kencana Prenada Media Group, 2012.

[4] A. Yasin, Ilmu Usul Fiqh “Dasar-Dasar Istinbat Hukum Islam”. Surabaya: UIN Sunan Ampel Surabaya, 2013.

[5] B. Ahmad Saebani, Sosiologi Agama. Bandung: PT. Refika Aditama, 2007.

[6] B. Arifin, Implikasi Prinsip Tasamuh (Toleransi) Dalam Interaksi Antar Umat Beragam. Jurnal Fikri, Vol. 1.

[7] D. Puryanti, Rosani, dan Dahlia Haliyah Ma'u, Ushul Fiqh dan Maqashid Syariah Tentang Istihsan Dalam Ekonomi Syariah.Jurnal Ekonomi Islam Qus-Qazah, Vol. 1, No.1.

[8] Departemen Agama RI, Al-Qur'an Dan Terjemahannya. Sukoharjo: Medina Qur'an, 2016.

[9] I. Syafe'i, Ilmu Ushul Fiqh. Bandung: Pustaka Setia, 2007.

[10] Kadenun, Istihsan Sebagai Sumber dan Metode Hukum Islam. Jurnal Qalamuna, Vol. 10.

[11] M. Abdullah, Pluralisme Agama Dan Kerukunan Dalam Keagamaa. Jakarta: Penerbit Buku Kompas, 2001.

[12] M. Ali Hasan, Berbagai Macam Transaksi Dalam Islam (Fiqh Muamalah). Jakarta: PT. Raja Grafindo Persada, 2003.

[13] M. Nashirudin, Istihsan dan Formulasinya (Pro KontraIstihsan Dalam Pandangan Mazhab Hanafi dan Syafi'i). Jurnal Asy-Syir'ah, Vol. 43.

[14] N. Harun, Fiqh Muamallah. Jakarta: Gaya Media Pratama, 2007.

[15] N. Haroen, Fiqh Muamalah. Jakarta: Gaya Media Pratama, 2007. 
[16] N. Naim, Islam Dan Pluralisme Agama Dinamika Perebukan Nama. Yogyakarta: Aura Pustaka, 2014.

[17] N. Naim, Islam dan Pluralisme Agama Dinamika Perebukan Nama. Yogyakarta: Aura Pustaka, 2014.

[18] Sudarsono, Pokok-Pokok Hukum Islam. Jakarta: Rieneka Cipta, 1992.

[19] Sugiyono, Metode Penelitian Pendidikan. Bandung: Alfabeta, 2012.

[20] S. K. Lubis, Hukum Ekonomi Islam. Jakarta: Sinar Grafika, 2004.

[21] R. SA, Pengantar Ilmu Ushul Fiqh. Depok: Kencana, 2017.

[22] W. al-Zuhaily, Al-Figh al-Islami Wa Adillah, Fiqh al-Sunnah. Damaskus: Dar al-Fikr al-Mu'ashir, 2005.

[23] W. Djunaedi, Fiqih, (Jakarta: PT. Lista Fariska Putra, 2008.

[24] https://www.bacaanmadani.com/2017/05/pengertian-istihsan-dasarhukum.html, diakses pada tanggal 17 November 2020. 